\title{
Synthesis and Biological Activity of Some 3, 5-Diarylisoxazoline Derivatives: Reaction of Substituted Chalcones with Hydroxylamine Hydrochloride
}

\author{
VANDANA SHARMA* and K.V. SHARMA \\ Department of Engineering Chemistry, \\ Mahakal Institute of Technology, Ujjain 456664, India. \\ vandanak_sharma@yahoo.co.in
}

Received 12 April 2009; Accepted 6 June 2009

\begin{abstract}
A series of 3-aryl-5-styrylisoxazoline/ 3,5-diarylisoxazoline derivatives were synthesized by the reaction of appropriately substituted chalcones and hydroxylamine hydrochloride in presence of alkali in ethanol. The synthesized heterocycles have been characterized on the basis of their chemical properties and spectroscopic data. These compounds were tested for biological activity against a variety of test organisms.
\end{abstract}

Keywords: Chalcones, Hydroxylamine hydrochloride, 3,5-Diarylisoxazoline, 3-Aryl-5-styrylisoxazoline.

\section{Introduction}

Among five membered heterocycles, isoxazoline represents a class of compounds of great importance in biological chemistry. For instance, isoxazoline posses biological activities ${ }^{1-8}$ like insecticidal, antibacterial, antibiotic, antitumour, antifungal, antituberculosis, anti inflammatory and analgesic. Isoxazoline also serves as anti-influenza virus activity ${ }^{9}$, inhibition of human leukocyte elastase and cathepsin $\mathrm{G}^{10}$. In fact, valdecoxib an isoxazoline derivative is now widely used in the market as anti-inflammatory drug ${ }^{11}$. Benzfuran isoxazolines serves as protein tyrosine phosphatase $1 \mathrm{~B}$ inhibitors ${ }^{12}$.

Some fluorinated methyliminobenzoxazolines and their derivatives have been patented as plant protecting acaricides, fungicides and insecticides ${ }^{13}$. Keeping in view the biological and medicinal importance of chalcones and isoxazolines, we have synthesized some isoxazolines starting from substituted 1,5-diaryl-2,4-pentadiene-1-one and hydroxylamine hydrochloride. 


\section{Experimental}

\section{General procedures}

Melting points were determined by the open tube capillary method and are uncorrected. The purity of the compounds was controlled by thin layer chromatography (TLC). IR spectra were recorded as $\mathrm{KBr}$ pellets on Perkin-Elmer spectrum RX1 spectrophotometer. Carbon, hydrogen and nitrogen were estimated by Thermo Finnigan FLASH EA 1112 elemental analyzer. Mass spectra were measured on JEOL SX 102/DA-6000 mass spectrometer. 3,5Diarylisoxazoline derivatives were prepared according to the reported methods.

\section{Synthesis of 1,5-diaryl-2,4-pentadiene-1-one (1)}

To a mixture of acetophenone $(8.12 \mathrm{~mL})$ and cinnamaldehyde $(8.8 \mathrm{~mL})$ in ethanol $(110 \mathrm{~mL})$ a solution of $\mathrm{NaOH}$ ( $10 \mathrm{~g}$ in $20 \mathrm{~mL}$ of water) was added. The reaction mixture was stirred for $4 \mathrm{~h}$ and then kept over night at room temperature. After cooling in ice, the reaction mixture was acidified with aqueous $\mathrm{HCl}(10 \%)$. The resulting precipitate was washed with distilled water and dried. The resulting crude was crystallized from ethanol to obtained yellow crystalline product.

\section{Synthesis of 3-aryl-5-styrylisoxazoline (1a)}

To a mixture of 1,5-diaryl-2,4-pentadiene-1-one (1 g) and hydroxylamine hydrochloride $(0.5 \mathrm{~g}$ in $5 \mathrm{~mL}$ water) in ethanol $(25 \mathrm{~mL})$ a solution of sodium hydroxide $(1.1 \mathrm{~g}$ in $10 \mathrm{~mL}$ water) was added. The reaction mixture was refluxed for $4 \mathrm{~h}$. It was allowed to cool at room temperature and then kept overnight in the freezer. A white crystalline solid separated. It was filtered, washed with distilled water and dried. The product was crystallized from ethanol to afford white crystals.

\section{Synthesis of 1-(4'-chlorophenyl)-5-phenyl-2,4-pentadiene-1-one (2)}

To a mixture of $p$-chloroacetophenone $(9.03 \mathrm{~mL})$ and cinnamaldehyde $(8.82 \mathrm{~mL})$ in ethanol $(110 \mathrm{~mL})$ a solution of $\mathrm{NaOH}(10 \mathrm{~g}$ in $20 \mathrm{~mL}$ water $)$ was added. The reaction mixture was stirred for $4 \mathrm{~h}$. It was then kept overnight at room temperature. After cooling in ice, the reaction mixture was acidified with aqueous $\mathrm{HCl}(10 \%)$. The resulting yellow solid was filtered, washed well with distilled water and dried. The product on crystallization from ethanol afforded yellow needles.

\section{Synthesis of 3-(4'-chlorophenyl)-5-styrylisoxazoline (2a)}

To a mixture of 1-(4'-chlorophenyl)-5-phenyl-2,4-pentadiene-1-one (1 g) and hydroxylamine hydrochloride $(0.5 \mathrm{~g}$ in $5 \mathrm{~mL}$ water $)$ in ethanol $(25 \mathrm{~mL})$ a solution of sodium hydroxide $(1.1 \mathrm{~g}$ in $10 \mathrm{~mL}$ water) was added. The reaction mixture was refluxed for $4 \mathrm{~h}$. It was allowed to cool to room temperature and then kept overnight in freezer. A white crystalline solid separated. It was filtered, washed with distilled water and dried. The product was crystallized from ethanol to afford white crystal.

\section{Synthesis of 1-(4'-methylphenyl)-5-phenyl-2,4-pentadiene-1-one (3)}

To a mixture of $p$-methylacetophenone $(9.31 \mathrm{~mL})$ and cinnamaldehyde $(8.82 \mathrm{~mL})$ in ethanol $(110 \mathrm{~mL})$ a solution of $\mathrm{NaOH}(10 \mathrm{~g}$ in $20 \mathrm{~mL}$ water) was added. The reaction mixture was stirred for $4 \mathrm{~h}$. It was then kept overnight at room temperature. After cooling in ice, the reaction mixture was acidified with aqueous $\mathrm{HCl}(10 \%)$. The resulting yellow solid was filtered, washed well with distilled water and dried. The product on crystallization from ethanol afforded yellow needles. 


\section{Synthesis of 3-(4'-methylphenyl)-5-styrylisoxazoline (3a)}

To a mixture of 1-(4'-methylphenyl)-5-phenyl-2,4-pentadiene-1-one (1 g) and hydroxylamine hydrochloride $(0.5 \mathrm{~g}$ in $5 \mathrm{~mL}$ water $)$ in ethanol $(25 \mathrm{~mL})$ a solution of sodium hydroxide $(1.1 \mathrm{~g}$ in $10 \mathrm{~mL}$ water) was added. The reaction mixture was refluxed for $4 \mathrm{~h}$. It was allowed to cool to room temperature and then kept overnight in freezer. A white crystalline solid separated. It was filtered, washed with distilled water and dried. The product was crystallized from ethanol to afford white crystal.

\section{Synthesis of 3-(4'-methoxyphenyl)-5-phenyl-2,4-pentadiene-1-one (4)}

To a mixture of $p$-methylacetophenone $(10.55 \mathrm{~mL})$ and cinnamaldehyde $(8.8 \mathrm{~mL})$ in ethanol $(110 \mathrm{~mL})$ a solution of $\mathrm{NaOH}(10 \mathrm{~g}$ in $20 \mathrm{~mL}$ water) was added. The reaction mixture was stirred for $4 \mathrm{~h}$. It was then kept overnight at room temperature. After cooling in ice, the reaction mixture was acidified with aqueous $\mathrm{HCl}(10 \%)$. The resulting yellow solid was filtered, washed well with distilled water and dried. The product on crystallization from ethanol afforded yellow needles.

\section{Synthesis of 3-(4'-methoxyphenyl)-5-styrylisoxazoline (4a)}

To a mixture of 1-(4'-methoxyphenyl)-5-phenyl-2,4-pentadiene-1-one (1g) and hydroxylamine hydrochloride $(0.5 \mathrm{~g}$ in $5 \mathrm{~mL}$ water $)$ in ethanol $(25 \mathrm{~mL})$ a solution of sodium hydroxide $(1.1 \mathrm{~g}$ in $10 \mathrm{~mL}$ water) was added. The reaction mixture was refluxed for $4 \mathrm{~h}$. It was allowed to cool to room temperature and then kept overnight in freeze. A white crystalline solid separated. It was filtered, washed with distilled water and dried. The product was crystallized from ethanol to afford white crystal.

\section{Synthesis of 3-phenyl-5-(2-hydroxyphenyl) isoxazoline (5)}

To a mixture of 2-hydroxychalcone $(2 \mathrm{~g})$ and hydroxylamine hydrochloride $(1 \mathrm{~g}$ in $10 \mathrm{~mL}$ water) in ethanol $(110 \mathrm{~mL})$ a solution of $\mathrm{NaOH}(10 \mathrm{~g}$ in $20 \mathrm{~mL}$ of water) was added in ethanol $(50 \mathrm{~mL})$.The reaction mixture was refluxed for $4 \mathrm{~h}$ and then kept over night at room temperature. After cooling in ice, the reaction mixture was acidified with aqueous $\mathrm{HCl}$ $(10 \%)$. The resulting precipitate was washed with distilled water and dried. The resulting crude was crystallized from ethanol to obtained white crystalline product.

\section{Synthesis of 3-(4'-methylphenyl)-5-(2-hydroxyphenyl) isoxazoline (6)}

To a mixture of 2-hydroxy-4'-methoxychalcone $(2 \mathrm{~g})$ and hydroxylamine hydrochloride $(1 \mathrm{~g}$ in $10 \mathrm{~mL}$ water $)$ in ethanol $(110 \mathrm{~mL})$ a solution of $\mathrm{NaOH}(10 \mathrm{~g}$ in $20 \mathrm{~mL}$ of water) in ethanol $(50 \mathrm{~mL})$ was added.The reaction mixture was refluxed for $4 \mathrm{~h}$ and then kept over night at room temperature. After cooling in ice, the reaction mixture was acidified with aqueous $\mathrm{HCl}$ $(10 \%)$. The resulting precipitate was washed with distilled water and dried. The resulting crude was crystallized from ethanol to obtained white crystalline product.

\section{1,5-Diaryl-2,4-pentadiene-1-one (1)}

Compound (1) was obtained as yellow crystals in $85 \%$ yield, m.p. $99-100{ }^{\circ} \mathrm{C}$; IR, $v_{\max }: 3200$, 2920, 1650, 1600, 1590, 1580, 1540, 1350, 1290, 1250, 1200, 1100, 1030, 1000, 820, 760 ,730, 690, 6000 and $480 \mathrm{~cm}^{-1}$; MS, m/z: 234, 233, 157, 131, 103, 77. Anal. Calcd. for $\mathrm{C}_{17} \mathrm{H}_{14} \mathrm{O}: \mathrm{C}, 87.17 ; \mathrm{H}, 5.98$, Found: C, 87.20; H, 5.88\%.

\section{3-Aryl-5-styrylisoxazoline (1a)}

Compound (1a) was obtained as white crystals in $80 \%$ yield, m.p. $171-172{ }^{\circ} \mathrm{C}$; IR, $v_{\max }$ : 3200, 2900, 1610, 1580, 1560,1500, 1440, 1410, 1360, 1260, 1060, 990, 960, 930, 760, 750, 700 and $580 \mathrm{~cm}^{-1}$; MS, m/z: 249, 248, 172, 171, 146,103, 77, 69. Anal. Calcd. for $\mathrm{C}_{17} \mathrm{H}_{15} \mathrm{NO}$ : C, 81.88; H, 6.02; N, 5.66, Found: C, 81.88; H, 6.02; N, 5.62;\%. 


\section{1-(4'-Chlorophenyl)-5-phenyl-2,4-pentadiene-1-one (2)}

Compound (2) was obtained as yellow crystals in $75 \%$ yield, m.p. $139-140{ }^{\circ} \mathrm{C}$; IR, $v_{\max }$ : $3010,2910,1650,1590,1580,1570,1450,1400,1350,1290,1260,1200,1150,1100,1030$, 1015, 990, 820, 730, 690, 670 and $480 \mathrm{~cm}^{-1}$; MS, m/z: 268, 267, 232, 190, 178, 166, 152, 112, 76. Anal. Calcd. for $\mathrm{C}_{17} \mathrm{H}_{13} \mathrm{ClO}$ : C, 75.58; H, 4.83 Found: C, 76.28; H, 4.29\%.

\section{3-(4'-Chlorophenyl)-5-styrylisoxazoline (2a)}

Compound (2a) was obtained as white crystals in $78 \%$ yield, m.p.173-174 ${ }^{\circ} \mathrm{C}$; IR, v max $: 3020$, 2930, 1610, 1590, 1550, 1530, 1490,1450, 1420, 1400, 1380, 1350, 1260, 1100, 1010, 980, $910,860,840,820,750,690,550,530,500$ and $450 \mathrm{~cm}^{1}$; MS, m/z:286, 285, 250, 209, 183 , 173, 148, 114, 79, 78, 71. Anal. Calcd. for $\mathrm{C}_{17} \mathrm{H}_{14}$ ClNO: C, 71.32; H, 4.89; N, 4.89. Found: C, 71.36; H, 4.78; N, 4.92\%.

\section{1-(4'-Methylphenyl)-5-phenyl-2,4-pentadiene-1-one (3)}

Compound (3) was obtained as yellow crystals in $71 \%$ yield, m.p. 88-89 ${ }^{\circ} \mathrm{C}$; IR, $v_{\max }: 3020$, 2920, 1650, 1600, 1580, 1560, 1450, 1350, 1290, 1260, 1190, 1160, 1120, 1030, 1020, 1000, 940, 880, 750, 730, 690 and $600 \mathrm{~cm}^{-1}$; MS, m/z: 248, 247, 233, 179, 171, 153, 145, 102, 91, 76. Anal. Calcd. for $\mathrm{C}_{18} \mathrm{H}_{16} \mathrm{O}: \mathrm{C}, 87.09 ; \mathrm{H}, 6.45$; N. Found: C, 87.13; H, 6.43\%.

\section{3-(4'-Methylphenyl)-5-styrylisoxazoline (3a)}

Compound (3a) was obtained as white crystals in $65 \%$ yield, m.p. $138-139{ }^{\circ} \mathrm{C}$; IR, $v_{\max }: 3020$, 2920, 1610, 1600, 1580, 1560, 1510, 1510, 1490, 1450, 1430, 1390, 1350, 1260, 1190, 180, 980, $950,910,830,810,750,700,620,550,530$ and $460 \mathrm{~cm}^{-1}$; MS, m/z: 261, 260, 246, 184, 169, 158, 143, 92, 89, 74,66. Anal. Calcd. for $\mathrm{C}_{18} \mathrm{H}_{17} \mathrm{NO}$ : C, 82.13; H, 6.46; N, 5.32 Found: C, 82.66; H, $5.79 ; \mathrm{N}, 5.36 \%$.

\section{3-(4'-Methoxyphenyl)-5-phenyl-2, 4-pentadiene-1-one (4)}

Compound (4) was obtained as yellow crystals in $76 \%$ yield, m.p. 83-84 ${ }^{\circ} \mathrm{C}$; IR, $v_{\max }: 3020$, 2940, 1650, 1600, 1590, 1510, 1450, 1420, 1360, 1310, 1290, 1260, 1175, 1120, 1030, 1010, 960, 820, 760, 740, 690, 640, 600 and $510 \mathrm{~cm}^{-1}$; MS, m/z: 264, 263, 233, 187, 179, 161, 153, 107, 102,76. Anal. Calcd. for $\mathrm{C}_{18} \mathrm{H}_{17} \mathrm{O}_{2}: \mathrm{C}, 81.81 ; \mathrm{H}, 6.06$; Found: C, 81.83; H, 6.09\%.

\section{3-(4'-Methoxyphenyl)-5-styrylisoxazoline (4a)}

Compound (4a) was obtained as white crystals in $72 \%$ yield, m.p. $109-110{ }^{\circ} \mathrm{C}$; IR, $v_{\max }: 3020$, 2930, 1610, 1590, 1560, 1515, 1490, 1450, 1430, 1350, 1260, 1180, 1120, 1040, 1030, 980, 910, 835, 750, 700, 620 and $550 \mathrm{~cm}^{-1}$; MS, m/z: 239, 238, 208, 162, 136, 131, 67, 62, 54, 36, 28. Anal. Calcd. for $\mathrm{C}_{18} \mathrm{H}_{17} \mathrm{NO}_{2}$ : C, 77.42; H, 6.09; N,5.02. Found: 77.88; H, 5.46; N, $5.05 \%$.

\section{3-Phenyl-5-(2-hydroxyphenyl) isoxazoline (5)}

Compound (5) was obtained as white crystals in 65\% yield, m.p. $149-150{ }^{\circ} \mathrm{C}$; IR $v_{\max }: 3200$ (-OH stretching vibration) $1610,1590,1570,1500,1460,1450,1360,1290,1270,1190$, $1170,1110,1050,1000,960,935,875,840,765,750,690,610,530$ and $480 \mathrm{~cm}^{-1}$; MS, $\mathrm{m} / \mathrm{z}: 239,238,222,162,153,143,93,76,68$. Anal. Calcd. For $\mathrm{C}_{15} \mathrm{H}_{13} \mathrm{NO}_{2}: \mathrm{C}, 75.31 ; \mathrm{H}$, 5.43; N, 5.85. Found: C, 75.29; H, 5.46; N, 5.92\%.

\section{3-(4'-Methylphenyl)-5-(2-hydroxyphenyl) isoxazoline (6)}

Compound (6) was obtained as white crystals in 75\% yield, m.p. $138-139{ }^{\circ} \mathrm{C}$; IR, $v_{\max }: 3200$ (-OH stretching vibration) 1610, 1590, 1570, 1500, 1460, 1450, 1360, 1290, 1260, 1180, $1155,1110,1085,1050,980,960,935,920,875,840,765,750,690,610,530$ and $480 \mathrm{~cm}^{-1}$; 
MS, m/z:253, 252, 238, 236, 161, 159, 144, 90, 75, 67, 58. Anal. Calcd. For $\mathrm{C}_{16} \mathrm{H}_{15} \mathrm{NO}_{2}: \mathrm{C}$, 75.88; H, 5.92; N, 5.53. Found: C, 75.86; H, 5.92; N, 5.55\%.

\section{Results and Discussion}

Keeping in view the biological activity and medicinal importance of chalcones and isoxazolines, we synthesized some isoxazolines starting from substituted 1,5-diaryl-2,4-pentadiene-1-ones and hydroxylamine hydrochloride. Substituted 1,5-diaryl-2,4-pentadiene-1-ones (1-4) have been prepared by variedly substituted acetophenones and cinnamaldehyde by Claisen-Schmidt condensation. These substituted 1,5-diaryl-2,4-pentadiene-1-ones and substituted 2hydroxychalcones were refluxed with hydroxylamine hydrochloride in presence of alkali in ethanol for $4 \mathrm{~h}$ to afford the corresponding 3-aryl-5-styrylisoxazoline (1a-4a) (Scheme 1) and 3,5-diarylisoxazolines $\mathbf{( 5 , 6 ) ( S c h e m e ~ 2 )}$ respectively. The structures of all new compounds have been elucidated by elemental analyses, mass and IR spectral measurements.
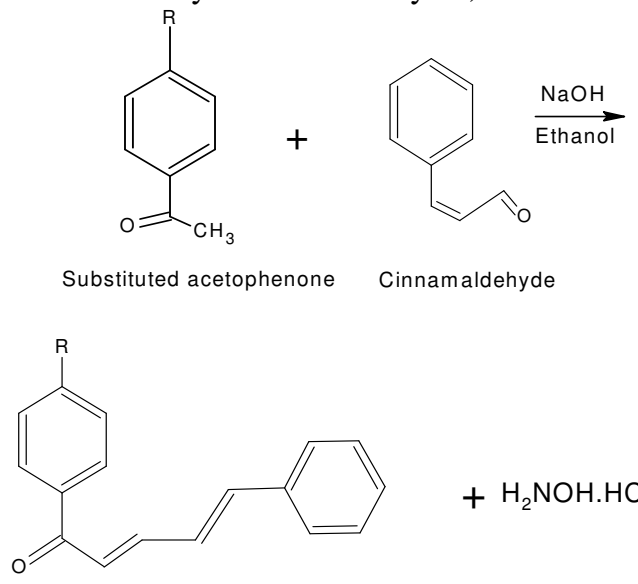

Substituted-1,5-diaryl-2,4-petadiene-1-one Hydroxylamine hydrochloride

(1-4)

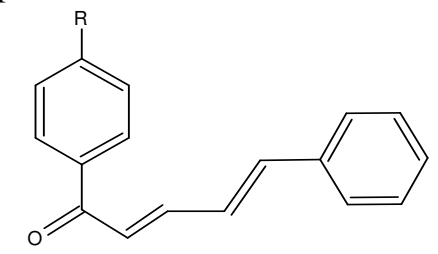

Substituted-1,5-diaryl-2,4-petadiene-1-one

$(1-4)$

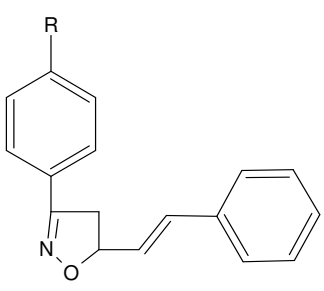

3-aryl-5-styrylisoxazoline

(1a-4a)

1,1a: $\mathrm{R}=\mathrm{H} ; \mathbf{2 , 2 a}: \mathrm{R}=\mathrm{Cl} ; \mathbf{3 , 3 a}: \mathrm{R}=\mathrm{CH}_{3} ;$ 4,4a: $\mathrm{R}=\mathrm{OCH}_{3}$

Scheme 1. Synthesis of substituted 1,5-diaryl-2,4-pentadiene-1-ones and 3-aryl-5styrylisoxazoline derivatives.

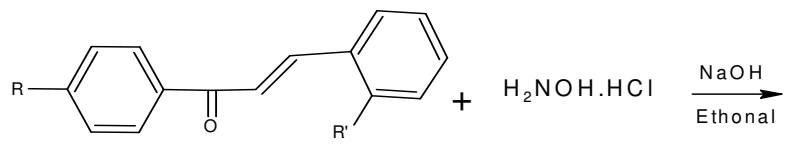

Substituted-2-hydroxy chalcone
Hydroxylam ine Hydrochloride

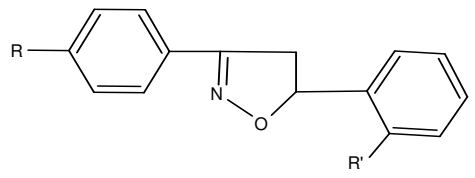

Substituted-3,5-diarylisoxazoline

$(5,6)$

5: $\mathrm{R}=\mathrm{H} ; \mathrm{R}^{\prime}=\mathrm{OH}, \mathbf{6}:=\mathrm{R}=\mathrm{CH}_{3} ; \mathrm{R}^{\prime}=\mathrm{OH}$

Scheme 2. Synthesis of substituted-3,5-diarylisoxazoline derivatives

IR spectra of 1,5-diaryl-2,4-pentadiene-1-ones give absorption peak at $1650 \mathrm{~cm}^{-1}$ due to $\mathrm{C}=\mathrm{O}$ group, this lowering in frequency is due to extended conjugation. A group of three bands were found in the region $1600-1500 \mathrm{~cm}^{-1}$. This is due to the absorption of aromatic nucleus and olefinic double bond. The IR spectra of isoxazolines show no carbonyl absorption peaks at $1610 \mathrm{~cm}^{-1}$ and $1260 \mathrm{~cm}^{-1}$ due to $\mathrm{C}=\mathrm{N}$ and $\mathrm{C}-\mathrm{O}-\mathrm{N}$ stretching frequencies respectively. 


\section{Biological activity}

The synthesized 3-aryl-5-styrylisoxazoline (1a-4a) and 3,5-diarylisoxazolines $(\mathbf{5 ,}, \mathbf{6})$ have been subjected to in vitro antimicrobial activity against various plant and human pathogenic bacteria and fungi. Antimicrobial activity was carried out against gram positive coccus Staphylococcus aureus, Micrococcus luteus, gram positive rod Bacillus megatherium and gram negative rod Pseudomonas aeruginosa, Proteus vulgaris and Klebsiella pneumoniae. Candida albicans, Saccharomyces cerevisiae yeast fungus and Aspergillus niger, Penicillium notatum soil fungi were used for microbial activity. The results are summarized in the Table 1.

Table 1. Antimicrobial activity of 3-aryl-5-styrylisoxazoline and 3,5-diarylisoxazoline derivatives.

\begin{tabular}{lcccccccccc}
\hline \multirow{2}{*}{ Compd. No. } & \multicolumn{10}{c}{ Culture } \\
\cline { 2 - 11 } & A & B & C & D & E & F & G & H & I & J \\
\hline $\mathbf{1}$ & 3 & 6 & & & & & & 4 & & \\
$\mathbf{1 a}$ & 4 & & 5 & & & & & 5 & 2 & 2 \\
$\mathbf{2}$ & 3 & & & & & & & 4 & & \\
$\mathbf{2 a}$ & 4 & 5 & & & & & & 5 & 2 & \\
$\mathbf{3}$ & 10 & 5 & 2 & 3 & 2 & & 9 & 7 & 7 & 3 \\
$\mathbf{3 a}$ & 10 & 5 & 3 & 3 & 3 & & & 5 & 8 & 5 \\
$\mathbf{4}$ & & 5 & & & & & & 4 & & \\
$\mathbf{4 a}$ & & & 2 & & & & & 5 & 2 & \\
$\mathbf{5}$ & 7 & 5 & 5 & 4 & & 4 & 10 & 3 & 10 & 2 \\
$\mathbf{6}$ & 6 & 6 & 4 & 5 & & 5 & 8 & 5 & 10 & 3 \\
\hline
\end{tabular}

(Diameter of inhibition zone measured in $\mathrm{mm}$, paper disc $5 \mathrm{~mm}$, inhibition zone measured excluding paper disc diameter)

$$
\begin{array}{lll}
\mathrm{A}=\text { Staphylococcus aureus; } & \mathrm{B}=\text { Micrococcus luteus; } & \mathrm{C}=\text { Bacillus megatherium; } \\
\mathrm{D}=\text { Pseudomonas aeruginosa } ; & \mathrm{E}=\text { Proteus vulgaris; } & \mathrm{F}=\text { Klebsiella pneumoniae; } \\
\mathrm{G}=\text { Aspergillus niger } ; & \mathrm{H}=\text { Penicillium notatum; } & \mathrm{I}=\text { Candida albicans; } \\
\mathrm{J}=\text { Saccharomyces cerevisiae. } &
\end{array}
$$

It can be concluded from the observation that, these substituted 3-aryl-5styrylisoxazoline $(\mathbf{1 a - 4 a )}$ and 3,5-diarylisoxazolines $(\mathbf{5}, \mathbf{6})$ possess moderate antimicrobial and antifungal activity. The larger inhibition growth was observed when all the compounds were tested against gram positive coccus Staphylococcus aureus and soil fungi Penicillium notatum. However, moderate inhibition growth was observed when all the compounds were tested with Micrococcus luteus, Candida albicans and Saccharomyces cerevisiae. The compounds were found to be inactive against gram negative bacteria Pseudomonas aeruginosa, Proteus vulgaris and Klebsiella pneumoniae.

In conclusion, we have synthesized a systematically substituted series of new 3-aryl-5styrylisoxazoline (1a-4a) and 3,5-diarylisoxazolines $(\mathbf{5}, \mathbf{6})$ derivatives for structure-activity relationship studies. These substituted derivatives are very stable compounds, which renders them beneficial substances for biological or pharmacological trials.

\section{Acknowledgements}

Authors are thankful to School of Studies in Chemistry, Vikram University, Ujjain (India), RSIC, CDRI, Lucknow (India), Mahakal Institute of Pharmaceutical Studies, Ujjain (India) for providing spectral and analytical data. 


\section{References}

1. Huisgen R, Angew Chem Int Ed Engl., 1963, 2, 565.

2. Caramella $\mathrm{P}$ and Grunanger P, In 1,3-Dipolar Cycloaddition Chemistry, Padwa A, Ed.; Wiley-Interscience, New York, 1984, 1, 337.

3. Barot V M, Oriental J Chem., 2000, 16, 177.

4. Ankhiwala M D and Hathi M V, J Indian Chem Soc., 1994, 71, 587.

5. Kedar R M, Vidhale N N and Chincholkar M M , Oriental J Chem., 1996, 12, 301.

6. Kedar R M, Oriental J. Chem., 1997, 13, 143.

7. Tangallapally R P, Sun D, Rakesh, Budha N, Lee R E B, Lenaerts A J M, Meibohm B, Lee R E, Bioorg Med Chem Lett., 2007, 17(23), 6638.

8. Habeeb A G, Praveen Rao P N and Knaus E E, J Med Chem., 2001, 44(18), 2921.

9. Hiroyuki K, Hiroshi M, Naohiko H, Akira T, Tamio F and Hirohiko S, Bioorg Med Chem Lett., 2001, 11(15), 1997.

10. Groutas W C, Chang L S, Epp J B, Venkataraman R, Brubaker M J, Stanga M A, Kim Eun-Hong and Keller C E, Bioorg Med Chem Lett., 1992, 2, 1571.

11. Dannahardt G, Kiefer W, Kramer G, Maehrlein S, Nowe U and Fiebich B. Eur J Med Chem., 2000, 35, 499.

12. Ahmad G, Mishra P K, Gupta P, Yadav P P, Tiwari P, Tamrakar A K, Srivastava A K and Maurya R, Bioorg Med Chem Lett., 2006, 16(8), 2139.

13. Buethner G, Klonke E, Frohberger E P and Hammann I, Ger Patent, 221832g, 1973, Chem. Abstr., 1974, 86, 14912. 


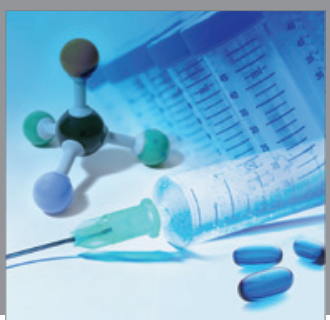

International Journal of

Medicinal Chemistry

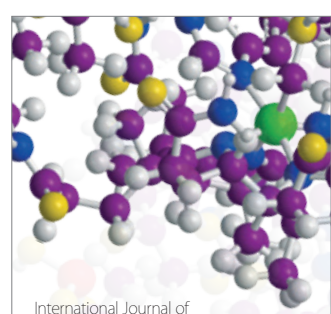

Carbohydrate Chemistry

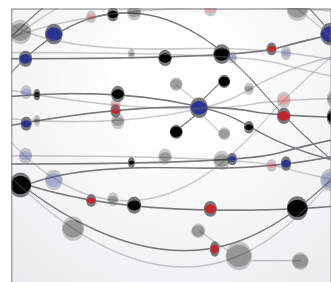

The Scientific World Journal
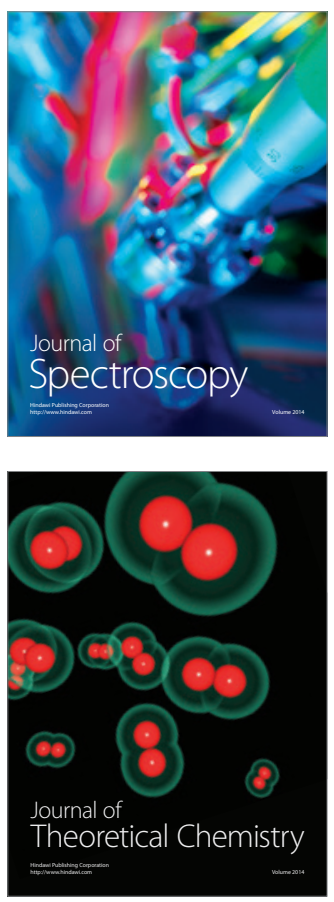
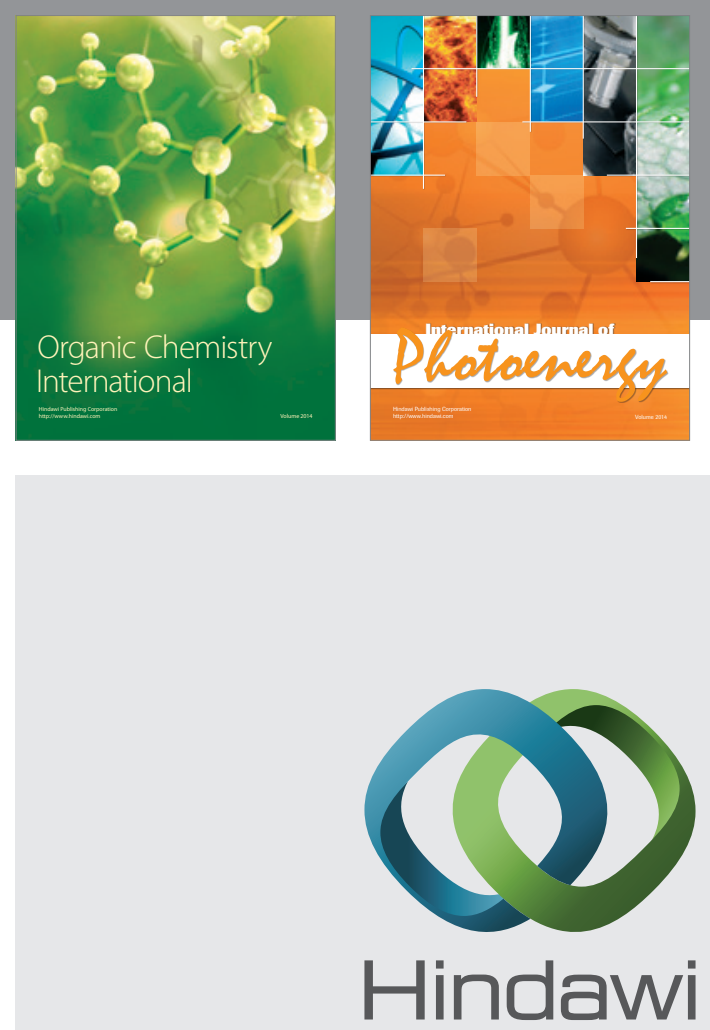

Submit your manuscripts at

http://www.hindawi.com
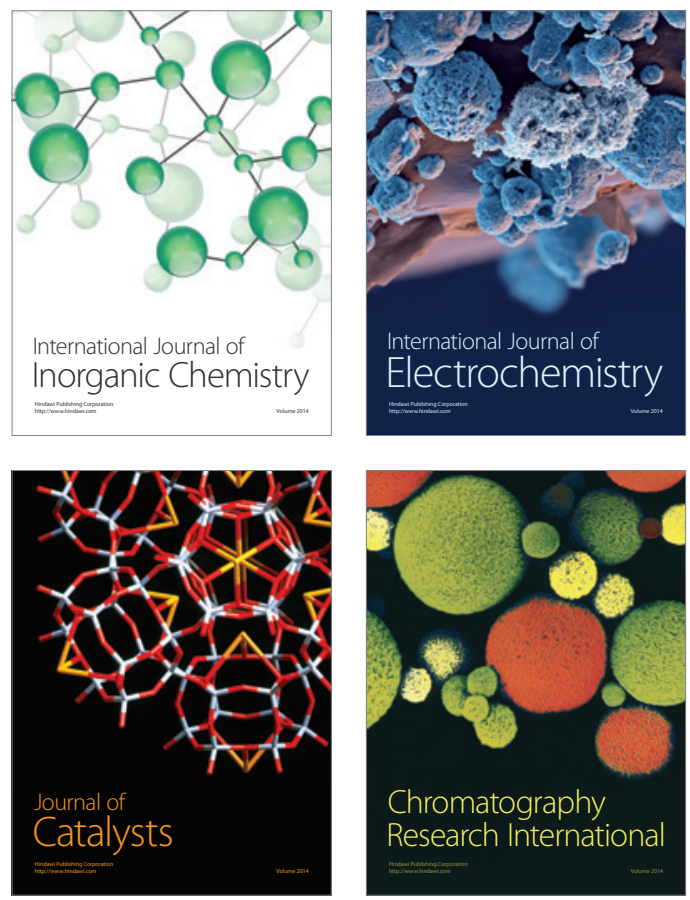
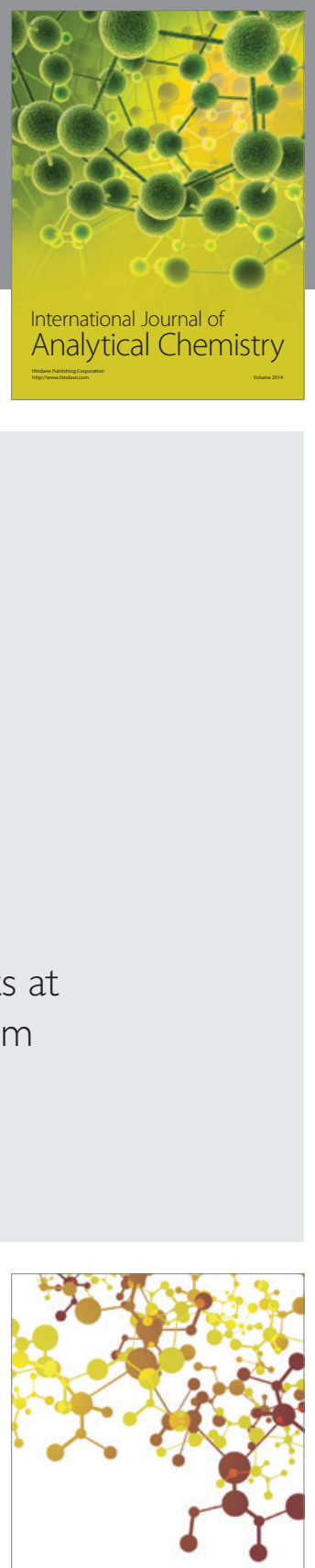

Journal of

Applied Chemistry
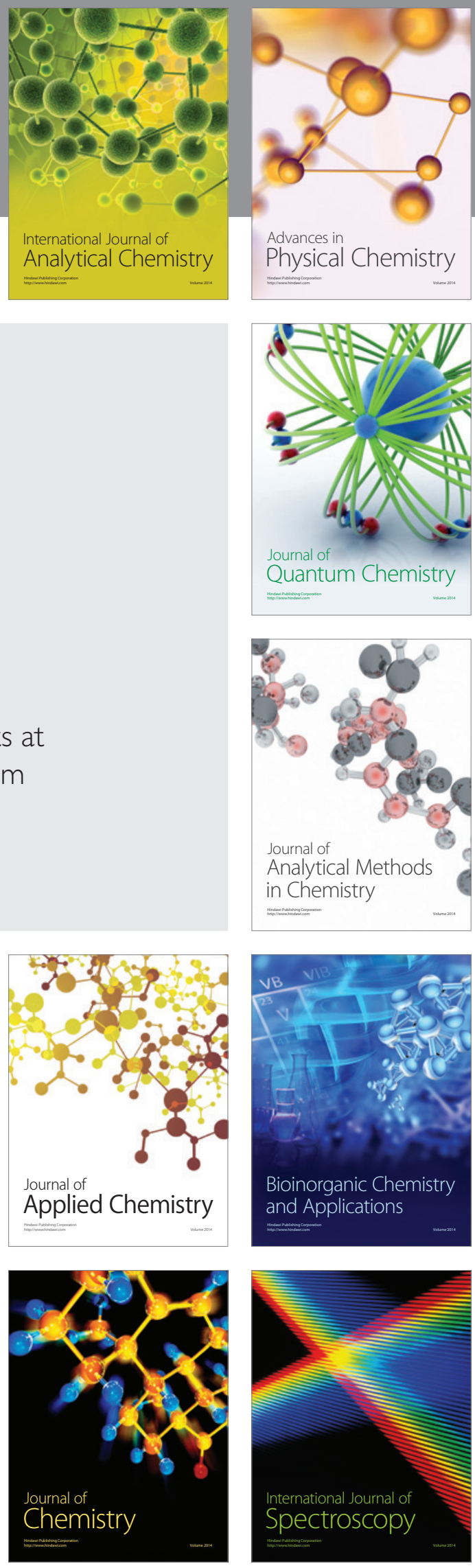